удК 947

\title{
B.A. Eсипова
}

\section{ДОКУМЕНТЫ О РАСПРОСТРАНЕНИИ ВИНА В СИБИРИ В ХVII В.: МАТЕРИАЛЫ НБ ТГУ И ТОКМ}

\author{
Статья подготовлена при частичной финансовой поддержке гранта РФФИ \\ и Администрации Томской области № 17-14-70006 ОГН ОГН_СИБ-А, а также гранта \\ Фонда им. Д.И. Менделеева (Национальный исследовательский Томский государственный университет. № 8.1.17.2018).
}

\begin{abstract}
Статья имеет целью введение в научный оборот неизвестного ранее документа, посвященного истории распространения в Сибири спиртных напитков в конце XVII в. Документ хранится в Томском областном краеведческом музее и позволяет рассмотреть вопросы учета и измерения объемов присланного вина, измерения содержащейся в вине доли спирта. Также в документе указаны имена поставщиков вина в Сибирь и перечислено, как именно оно распределялось. Установлено, что в Научной библиотеке ТГУ хранится еще один документ, составляющий, наряду с публикуемым текстом, часть служебной переписки сибирских воевод по указанным вопросам.

Ключевые слова: Сибирь; винокурение; исторический источник.
\end{abstract}

Исследователи уже неоднократно обращались к истории винокурения и распространения вина в Сибири [1-4], однако они вынуждены были констатировать, что вопрос о производстве и потреблении вина в Сибири в XVII в. до сих пор изучен не до конца. Основной причиной является плохая сохранность документов, которые к тому же рассредоточены по разным хранилищам от сибирских городов до Москвы и не все еще введены в научный оборот.

Один из таких документов хранится в отделе рукописей и книжных памятников Научной библиотеки Томского университета (ОРКП НБ ТГУ), он опубликован как в традиционном, так и в электронном виде и был известен еще И.И. Тыжнову, который готовил текст к публикации [5. С. 77; 6. С. 123125]. Это отписка тобольских воевод М.Я. и П.М. Черкасских тарскому воеводе М.И. Вельяминову о приеме от Петра Григорьева остаточного вина и о посылке на Тару ведра, аршина и опытного вина от 19 августа 1698 г. [7]. Необходимо отметить, что в работе Д.В. Раева, специально посвященной рассмотрению кружечных дворов Западной Сибири во второй половине XVII - начале XVIII в., о Таре не говорится вообще, что автор объясняет плохой сохранностью источниковой базы.

В документе поднимается ряд вопросов, связанных с распространением вина в Сибири. Так, там описывается процесс доставки вина из европейской части России: в Сибирском приказе в Москве енисейский посадский человек Якушка Кулаков подрядился поставить вино на Тару. В отписке сообщается, что в текущем году вино и «опыты вину в скляницах» были поставлены представителем купца Алексея Ушакова Петром Артемьевым Григорьевым. Однако возникли проблемы с измерением количества доставленного вина, возникло сомнение, что имеющаяся мерка («заорленое ведро») не соответствует стандарту. В результате в Москве было заказано новое ведро для мерки. Таким образом, в документе поднимаются вопросы доставки вина в Сибирь, а также вопросы его учета и измерения количества.

В Томском областном краеведческом музее (ТОКМ) хранится еще один образец переписки между теми же персонами по аналогичному поводу; этот документ еще не вводился в научный оборот [8]. Это также отписка тобольских воевод М.Я. и П.М. Черкасских тарскому воеводе М.И. Вельяминову об опытах вину. Отписка долгое время находилась в экспозиции ТОКМ, предпринимались отдельные попытки прочесть ее текст, однако работа по введению в научный оборот этого документа не была доведена до конца. Поэтому было принято решение извлечь документ из экспозиции, выполнить его оцифровку, полное палеографическое описание и транскрипцию текста. В настоящее время этот комплекс работ выполнен и по его итогам можно сказать следующее.

Точная дата в документе отсутствует; можно датировать его второй половиной 1698 - первой половиной 1699 г. Сузить датировку документа позволяет запись на обороте: указано, что отписка подана адресату тарским пушкарем Андреем Лычагиным 19 августа 1698 г., что означает, что написана она ранее этой даты. Отметим, что документы написаны разными почерками; в случае документа ТОКМ почерк более крупный и практически без наклона, в то время как отписка из НБ ТГУ написана более небрежно, с видимым наклоном вправо. В документе говорится о том, что на Тару из Тобольска отправлена партия вина «для погребной дачи» с тарским пушкарем Андреем Лычагиным; отметим, что именно Лычагин являлся подателем первого документа, хранящегося в НБ ТГУ. Также всем воеводам рекомендовано «чинить опыт» присланному вину: «налить мерку / чарки ввде и звесить и жечь. И сколко / ево угорит, и по весу и по мере остан/нетца, то ему и свидетелство за пе/чатью опыт послать».

Как видно, в тексте отписки воспроизводится почти дословно одно из положений указа Петра I от 22 ноября 1689 г. [9]. Указ, в числе прочего, закреплял, видимо, хорошо известный и до этого способ определения крепости вина - отжиг. Очевидно, именно на этот указ и ссылается настоящая отписка, когда оговаривает, что «послан/ному вину по грамоте великого / государя велено опыт чинить». Ниже приводятся и результаты произведенного «опыта»: «погребною чаркою в мерку налита / чарки вина по весу пятнатцать / золотников, и 
то вино зажжено /и угорело того вина по весу / шесть золотников, а осталос того / вина по весу девять золотников». Учитывая, что золотник составлял около 4,26 г, в чарку было налито 63,9 г, угорело 25,56 г, а осталось 38,34 г. Таким образом, содержание спирта в описанном опыте составляло порядка $40 \%$.

В отписке также оговаривалось, куда следует направить полученное на Таре вино: его предполагалось раздать тарским служилым людям на праздники, а также «ясашным / иноземцом для ясашнаго платежа».

Как было установлено, документ ТОКМ также готовился к публикации И.И. Тыжновым [5. С. 78], однако составленное им описание показывает, что в распоряжении Тыжнова мог быть другой экземпляр. Основной текст совпадает, но отличаются записи на обороте: в случае рассматриваемого документа присутствуют указания на адресата («Господину Митрофану Ивановичю») и о подаче отписки пушкарем Андреем Лычагиным. Тыжнов же указывает, что на обороте документа имеется еще запись «О посылке вина на Тару», которая отсутствует в экземпляре ТОКМ. К сожалению, в воспроизведении текста, выполненном Тыжновым, отсутствует указание на разделение строк и листов, поэтому невозможно установить, совпадает ли распределение текста по строкам.

Таким образом, в ТОКМ хранится документ, который показывает начало проведения в жизнь петровского указа от 22 ноября 1689 г. Важно, что, помимо пересказа текста о произведении замера доли спирта, в тексте приводятся и результаты собственно опыта, произведенного с присланным из Москвы вином. В целом два описанных выше документа дают представление о различных сторонах распространения вина в Сибири в конце XVII в.: здесь присутствуют вопросы учета и измерения объемов присланного вина, измерения содержащейся в вине доли спирта. Также указаны имена поставщиков вина в Сибирь и перечислено, как именно оно распределялось. Описанный выше документ из ОРКП НБ ТГУ составляет, наряду с публикуемым текстом, часть служебной переписки сибирских воевод между собой по вопросам реализации указа от 22 ноября 1698 г.

Ниже приводится описание и текст отписки, хранящейся в ТОКМ. Текст воспроизведен по следующим правилам: написание приведено к современной орфографии, сохранены только вариативные написания, отражающие произношение; титла раскрыты, все выносные буквы внесены в строку без оговорок; пунктуация проставлена в соответствии с современными правилами. Разделение на строки показано одинарной косой чертой, разделение листов - двойной косой чертой.

ТОКМ 14374. 1698 г., августа до 19. Отписка тобольских воевод кн. Михаила Яковлевича и Петра Михайловича Черкасских тарскому воеводе Митрофану Ивановичу Вельяминову об опытах вину. 2 л.
Бумага ручной выделки, филигрань «голова шута». $69,0 \times 16,5$ см.

На обороте почерком основной рукописи: «Господину Митрофану Ивановичю»; там же, чернилами, скорописью XVII в. отметка о подаче отписки 19 августа 1698 г. пушкарем Андреем Лычагиным. На лицевой стороне чернилами, скорописью XVIII в.: «№ 61», фиолетовыми чернилами, скорописью XX в.: «ТОМ ИО № 1097».

Воспроизведение текста: Тыжнов, № 71. С. 77.

(л. 1) Господину Митрофану Ивановичу Михайло да Петр / Черкаские челом бьют. В нынешнем в 206-м году / по указу великого государя и по грамотам, послано / ис Тоболска на Тару служилым людем и ясашным иноземцом на погребную дачю против / прошлого 205-го году тоболского куренья вина / дватцать семь ведер с полуведром / четыре чарки погребных с тарским / с пушкарем с Ондрюшкою Лычагиным / с товарыщив дубовой бочке, а послан/ному вину по грамоте по грамоте великого / государя велено опыт чинить, налить мерку / чарки ввде и звесить и жечь. И сколко / ево угорит, и по весу и по мере остан/нетца, то ему и свидетелство за пе/чатью опыт послать с посланным / вином в городы и к воеводам / писать о том имянно, чтоб они, воеводы, / у посылщиков вино приняв, чинили / опыт также зжением, и о том / в Тоболеск писали. И буде по их воево/дцким отпискам то вино будет / несходно, и про тех посылщиков розы/скивать, и по сыску на них за то вино / править безо всякие пощади денги / по указной цене. А им чинить наказанье / смотря по винам и по людям, чтоб / на то смотря иным так делать / неповадно было. И по тому вышепи/санному великого государя указу, посланному / вышеписанному вину в Тоболску / учинен опыт московскою присылкою / погребною чаркою в мерку налита / чарки вина по весу пятнатцать / золотников, и то вино зжено /и угорело того вина по весу / шесть золотников, а осталос того // (л. 2) вина по весу девять золотников. / И того вышеписанного вина / опыт в склянице за печатью /великого государя Тоболскою печатью / послали ис Тоболска на Тару / с вышеписанными тарскими пу/шкарем, с Ондршкою Лычагиным / с товарыщи. И как он с тем / вином на Тару приедут, и тебе б / велеть то вино у них принять / против опыту и для подлинного / свидетелства того вина учинить / опыт по вышеписанному указу. / И то вино записать в приходную / книгу и роздать тарским служи/лым людем на три указные празни/ка на нынешней 206-й год, и ясашным / иноземцом для ясашнаго платежу / по грамотам великого государя, каковые / посланы на Тару, и записать в росход / и в сметной список особ статьею, / а которые бочки дубовые с вином / присланы на Тару, и те бочки / прислать в Тоболеск, и о том к нам писать.

\section{ЛИТЕРАТУРА}

1. Прыжов И.Г. История кабаков в России. М. : Юрайт, 2018. 228 с.

2. Потехин Л. Винокурение в Сибири // Промышленность, мануфактура и торговля. 1862. Т. VI. № 10.

3. Раев Д.В. Кружечные дворы городов Западной Сибири (вторая половина XVII - начало XVIII в.). Новосибирск : «Сова», 2005.274 с.

4. Зиновьев В.П. Традиции сибирского винокурения в XVIII-XIX вв. // Вестник Томского государственного университета. История. 2008. № 1 (2). С. 13-23. 
5. Тыжнов И.И. Тарские акты XVII века / сост. В.А. Есипова, Д.Я. Резун, Н.В. Васенькин. Томск, 2012.120 с. URL: http://vital.lib.tsu.ru/vital/access/manager/Repository/vtls:000440329

6. Первое столетие освоения Сибири русскими. Новые документы : собрание сибирских грамот XVII - начала XVIII веков в фондах Научной библиотеки Томского государственного университета / сост. B.A. Есипова, Г.Н. Старикова. Томск : Изд-во Tом. ун-та, 1999. URL: http://vital.lib.tsu.ru/vital/access/manager/Repository/vtls:000068296

7. ОРКП НБ ТГУ. В-8520. Л. 2-4. Отписка тобольских воевод кн. Михаила Яковлевича и Петра Михайловича Черкасских тарскому воеводе Митрофану Ивановичу Вельяминову о приеме от Петра Григорьева остаточного вина и о посылке на Тару ведра, аршина и опытного вина / на об. адрес, отметка о теме отписки расписка в подаче отписки 19 августа 1698 г. пушкарем Андреем Лычагиным. Тобольск, 1698, августа до 19. URL: http://vital.lib.tsu.ru/vital/access/manager/Repository/vtls:000499290

8. ТОКМ 14374. 2 л. Отписка тобольских воевод кн. Михаила Яковлевича и Петра Михайловича Черкасских тарскому воеводе Митрофану Ивановичу Вельяминову об опытах вину. Тобольск, 1698 г., августа до 19.

9. Указ № 1655 от 22 нояб. 1698 г.: О ведении в Сибири кабаков таможенным Головам, а не Воеводам, и об управлении питейными сборами // Полное собрание законов Российской Империи. Собр. 1-е. СПб., 1830. Т. 3. С. 517-523.

Статья представлена научной редакцией «История» 15 октября 2018 г. DOCUMENTS ON THE DISTRIBUTION OF WINE IN SIBERIA IN THE 17TH CENTURY: MATERIALS OF TOMSK
STATE UNIVERSITY RESEARCH LIBRARY AND TOMSK MUSEUM OF LOCAL HISTORY

Vestnik Tomskogo gosudarstvennogo universiteta - Tomsk State University Journal, 2018, 436, 148-150. DOI: $10.17223 / 15617793 / 436 / 17$

Valeriya A. Esipova, Tomsk State University (Tomsk, Russian Federation). E-mail: esipova_val@mail.ru

Keywords: Siberia distillery; historical source.

The aim of the article is to introduce into scientific discourse a previously unknown document on the distribution of wine in Siberia in the 17th century. Researchers have repeatedly turned to the history of the spread of wine in Siberia in the 17th century; however, they have to admit that the problem has not yet been studied thoroughly. The reason is the poor safety of documents, which are stored in different places from the Siberian cities to Moscow and not fully introduced into scientific discourse. One of the documents on the topic is kept in the Rare Books and Manuscripts Department of Tomsk State University Research Library (ORKP NB TGU), it is published both in the traditional and in electronic form. It is a letter from Tobolsk Governors M.Ya. and P.M. Cherkassky to Tara Governor Velyaminov on receiving the remaining wine from P. Grigoriev (August 19, 1698). The document raises a number of issues related to the spread of wine in Siberia: for example, it describes the delivery of wine from the European part of Russia. One more sample of correspondence between the Tobolsk governors and the Tara governor is kept in the Tomsk Museum of Local History (TOKM), it is a letter about wine inspection. The document was in the exposition of TOKM for a long time, separate attempts were made to read its text, but the work on the introduction of the document into scientific discourse was not completed. It was found that the exact date is missing in the document; it is possible to date it by the second half of 1698 - the first half of 1699 . In the document, all governors were recommended to make a test of the wine sent. One of the provisions of the decree of Peter I (November 22, 1698) was reproduced in the document almost verbatim: it fixed a well-known method of determining the strength of wine - annealing. It was also stipulated in the document, where the wine received in Tara should be sent: it was supposed to be given to Tara servant and yasak people for holidays. Thus, the document from TOKM shows the beginning of the implementation of Peter's decree of November 22, 1689. In general, the two documents described above give an idea of the various aspects of wine distribution in Siberia at the end of the 17th century: recording and measuring the volumes of wine, determining the strength of wine. The names of wine suppliers to Siberia also are listed, as well as ways of wine distribution. The document from ORKP NB TGU, described above, makes, along with the text published, part of official correspondence of the Siberian governors on the implementation of Peter's decree of November 22, 1689. The article contains a paleographic description and the full text of the document from TOKM, which thus is introduced into scientific discourse.

\section{REFERENCES}

1. Pryzhov, I.G. (2018) Istoriya kabakov v Rossii [History of taverns in Russia]. Moscow: Yurayt.

2. Potekhin, L. (1862) Vinokurenie v Sibiri [Distilling in Siberia]. Promyshlennost', manufaktura i torgovlya. VI(10).

3. Raev, D.V. (2005) Kruzhechnye dvory gorodov Zapadnoy Sibiri (vtoraya polovina XVII - nachalo XVIII v.) [Taverns of cities in Western Siberia (second half of the 17 th - beginning of the 18th centuries)]. Novosibirsk: "Sova".

4. Zinov'ev, V.P. (2008) Tradition of Siberian brandy-distillery on the XVIII-XIX centuries. Vestnik Tomskogo gosudarstvennogo universiteta. Istoriya - Tomsk State University Journal of History. 1 (2). pp. 13-23. (In Russian).

5. Tyzhnov, I.I. (2012) Tarskie akty XVII veka [Tara Acts of the 17th century]. Tomsk: [s.n.]. [Online] Available from: http://vital.lib.tsu.ru/vital/access/manager/Repository/vtls:000440329.

6. Esipova, V.A. \& Starikova, G.N. (1999) Pervoe stoletie osvoeniya Sibiri russkimi. Novye dokumenty: sobranie sibirskikh gramot XVII - nachala XVIII vekov $v$ fondakh Nauchnoy biblioteki Tomskogo gosudarstvennogo universiteta [The first century of the development of Siberia by Russians. New documents: A collection of Siberian documents of the 17th - early 18th centuries in the funds of the Research Library of Tomsk State University]. Tomsk: Tomsk State University, [Online] Available from: http://vital.lib.tsu.ru/vital/access/manager/Repository/vtls:000068296.

7. Rare Books and Manuscripts Department of Tomsk State University Research Library. V-8520. P. 2-4. Otpiska tobol'skikh voevod kn. Mikhaila Yakovlevicha i Petra Mikhaylovicha Cherkasskikh tarskomu voevode Mitrofanu Ivanovichu Vel'yaminovu o prieme ot Petra Grigor'eva ostatochnogo vina i o posylke na Taru vedra, arshina i opytnogo vina / na ob. adres, otmetka o teme otpiski raspiska vodache otpiski 19 avgusta 1698 g. pushkarem Andreem Lychaginym. Tobol'sk, 1698, avgusta do 19 [Letter from Tobolsk Governors Princes Mikhail Yakovlevich and Pyotr Mikhailovich Cherkassky to Tara Voivode Mitrofan Ivanovich Veliyaminov about receiving residual wine from Pyotr Grigoriev and about sending a bucket, arshin and wine for testing to Tara / on the back: address, a note on the subject of the letter, signed of sending the letter on August 19, 1698 by the gunner Andrei Lychagin]. [Online] Available from: http://vital.lib.tsu.ru/vital/access/manager/Repository/vtls:000499290

8. Tomsk Museum of Local History. 14374. 2 1. Otpiska tobol'skikh voevod kn. Mikhaila Yakovlevicha i Petra Mikhaylovicha Cherkasskikh tarskomu voevode Mitrofanu Ivanovichu Vel'yaminovu ob opytakh vinu. Tobol'sk, 1698 g., avgusta do 19 [Letter from Tobolsk Governors Princes Mikhail Yakovlevich and Pyotr Mikhaylovich Cherkassky to Tara Voivode Mitrofan Ivanovich Veliyaminov about the tests of wine. Tobolsk, 1698, August 19].

9. Russian Empire. (1830) Ukaz № 1655 ot 22 noyab. 1698 g.: O vedenii v Sibiri kabakov tamozhennym Golovam, a ne Voevodam, i ob upravlenii piteynymi sborami [Decree No. 1655 of 22 Nov. 1698: On the maintenance of taverns in Siberia to the customs heads, and not the governors, and on the management of alcohol taxes]. Polnoe sobranie zakonov Rossiyskoy Imperii [Complete Collection of the Laws of the Russian Empire]. Collection 1. Vol. 3. St. Petersburg. pp. 517-523. 